\title{
Nucleotide sequence determination of the partial SSU rDNA gene and ITS1 region of Hematodinium cf. perezi and Hematodinium-like dinoflagellates
}

\author{
Darryl A. Hudson*, Robert D. Adlard \\ Department of Parasitology, The University of Queensland, Brisbane, Queensland 4072, Australia
}

\begin{abstract}
Partial sequences of the small subunit (SSU) rDNA gene of the parasitic dinoflagellates Hematodinium cf. perezi from the blue crab Callinectes sapidus and 3 Hematodinium-like organisms from other decapods, Nephrops norvegicus, Chionoecetes bairdi and C. opilio, were compared. The V9 variable domain of this gene showed no nucleotide differences between the 4 parasitic dinoflagellates. Comparison of this region with other protozoans suggested that the 3 Hematodinium-like organisms should be considered to be within the genus Hematodinium. Differences in nucleotide sequence in the partial ITS1 regions from these 4 parasitic dinoflagellates suggest that there are 2 new species. The Hematodinium organism ex $N$. norvegicus warrants the creation of a new species. The Hematodinium organisms ex $C$. barrdi and $C$. opilio are probably the same species and also warrant the creation of another new species, while $H$. cf. perezi remains distinct from the other isolates.
\end{abstract}

KEY WORDS: Hematodinium 18S/ITS1 rDNA genes - Molecular taxonomy

\section{INTRODUCTION}

Marine crustaceans are parasitized by 2 orders of dinoflagellates: the Blastodiales and the Syndiniales (Shields 1994). In the Syndiniales, the type species, Hematodinium perezi Chatton \& Poisson, 1931, was described from the portunid crabs Carcinus maenus and Portunus depurator; the second species, $H$. australis Hudson \& Shields, 1994, was described from another portunid, Portunus pelagicus. $\mathrm{H}$. cf. perezi has also been recorded from Callinectes sapidus, a decapod of commercial importance (Newman \& Johnson 1975, Messick 1994). Hematodinium-like dinoflagellates have had severe effects on Chionoecetes bairdi, C. opilio and Nephrops norvegicus, all decapods of commercial importance (Meyers et al. 1987, Field et al. 1992)

Hudson \& Shields (1994) have suggested that the taxonomy of the genus Hematodinium requires better

•E-mail: pa104020@mailbox.uq.oz.au definition. Taxonomic studies are difficult because electron microscope studies from the type species have not been undertaken and dinospores have not been recorded. The paucity of morphological characters useful for diagnosis of parasites from different hosts further complicates the systematics of the group.

Nucleotide sequence determination of the small subunit (SSU) ribosomal DNA (IDNA) gene and the internal transcribed spacer 1 (ITS1) region has proved a useful diagnostic tool at the levels of genus and species in insects (Porter \& Collins 1991), trematodes (Adlard et al. 1993) and protozoans (Cai et al. 1992, Goggin 1994, Diggles \& Adlard 1995). Our aim was to determine and compare partial SSU rDNA and ITS1 regions of Hematodinium cf. perezi and 3 Hematodinium-like dinoflagellates. These partial SSU sequences were compared to 6 other dinoflagellates to investigate the systematic distance between members of the genus Hematodinium and the organisms classified currently as Hematodinium-like, while the partial ITS1 sequences were used to determine the extent of genetic variance between isolates. 


\section{MATERIALS AND METHODS}

Sample collection. A sand crab, Portunus pelagicus, infected with Hematodinium australis was collected in March 1992, from Moreton Bay, Queensland, Australia. A Norway lobster, Nephrops norvegicus, infected with a Hematodinium-like dinoflagellate was collected in January 1993, from the Firth of Clyde, on the west coast of Scotland, UK. Two blue crabs, Callinectes sapidus, infected with Hematodinium cf. perezi were collected in November 1993, from the Rappalamoda River, Chesapeake Bay, Virginia, USA. Two Tanner crabs, Chionoecetes bairdi, infected with a Hematodinium-like dinoflagellate and a Snow crab, C. opilio, infected with a Hematodinium-like organism were collected in February 1993, near Juneau and Dutch Harbor, Alaska, USA, respectively. H. australis from $P$. pelagicus was frozen at $-60^{\circ} \mathrm{C}$. Hemolymph samples from Chionoecetes bairdi, $C$. opilio, and $N$. norvegicus containing Hematodinium-like dinoflagellates were collected via syringe and fixed directly in $100 \%$ ethanol. Hematodinium-infected testes from Callinectes sapidus were fixed directly in $100 \%$ ethanol and were shaken to produce sediment containing the Hematodinium cells. Attempts to obtain samples of the type species, $H$. perezi, from France were unsuccessful.

DNA extraction, purification and amplification. DNA was extracted from the Hematodinium organisms using a standard phenol/chloroform method as described by Hudson \& Adlard (1994). The first internal transcibed spacer (ITS1) of ribosomal DNA and flanking $3^{\prime}$ end of the SSU was amplified by polymerase chain reactions (PCR) using oligonucleotide primers, Primer 1 (forward primer: 5' GTT CCC CTT GAA CGA GGA ATT C) and Primer 2 (reverse primer: 5' CGC ATT TCG CTG CGT TCT TC). PCR amplifications were performed on Hematodinium organisms from Chionoecetes bairdi, C. opilio, Callinectes sapidus, Nephrops norvegicus and Portunus pelagicus as described by Hudson \& Adlard (1994). Hudson \& Adlard (1994) showed that Primers 1 and 2 favoured the amplification of dinoflagellate DNA. PCR products were purified (Magic PCR Preps, Promega) prior to sequencing. Primers were designed from published sequences available through GenBank: Primer 1, from conserved arthropod sequences; Primers 2 and 3, from conserved protozoan sequences; Primer 4, 100\% conserved sequences from yeasts to rabbits $i$ Primer 5 , from conserved eukaryotic sequences

DNA sequencing and analysis. DNA sequencing was by the dideoxy chain termination method (Sanger et al. 1977) using a dsDNA cycle sequencing kit (Gibco/BRL). Five primers were used for sequencing: Primer 1; Primer 2; Primer 3 (forward primer, 5' GTC
CCT GCC CTT TGT ACA CA); Primer 4 (forward primer 5 ' CGT AGG TGA ACC TGC GGA AGG ATC); and Primer 5 (reverse primer 5' GAT CCT TCT GCA GGT TCA CCT AC). Sequencing primers were endlabelled with phosphorus $\left({ }^{32} \mathrm{P}\right)$. Both the sense and the non-sense strands were sequenced for the partial SSU, while only the sense strand was sequenced for the partial ITS1 region as Primer 2 failed to produce a readable sequence. However, for the partial ITS1 region Primers 1, 3 and 4 produced identical sequences therefore validating results. Sequencing fragments were electrophoresed at a constant power of $45 \mathrm{~W}$.

DNA sequences were aligned by eye and manipulated with the Eye-ball Sequence Editor (ESEE) software (Cabot \& Beckenbach 1989). The partial SSU sequences minus the amplification primer scquencc, Primer 1, of Hematodinium organisms were compared to known sequences stored in Genbank using the Basic Local Alignment Search Tool (BLAST) routine (Altschul et al. 1990) available through the Australian National Genomic Information System (ANGIS). A total of 6 species from 3 dinoflagellate orders were compared. They were: Order Prorocentrales, Prorocentrum micans; Order Phytodiniales, Gloeodinium viscum; Order Gymnodiniales, Family Zooxanthellaceae, Symbiodinium microadriaticum, S. corculorum, S. pilosum, S. meandrinae. Gaps introduced into the alignment were treated as missing data. Informative sites are bases which are different for 1 sequence but similar in other sequences. A similarity matrix was used to establish relatedness in the V9 domain of the partial SSU region and for the partial ITS1 region.

\section{RESULTS}

Strong PCR products of approximately 680 base pairs were obtained from the Hematodinium spp. and the Hematodinium-like organisms (see Hudson \& Adlard 1994). These products were then sequenced. Sequences were obtained for 237 bases from the $3^{\prime}$ end of the SSU region (Fig. 1) and 278 bases from the $5^{\prime}$ end of the ITS1 region (Fig. 2) for Hematodinium cf. perezi (Isolate designation \#1) and the Hematodinium-like organisms from Nephrops norvegicus (Isolate designation \#2), Chionoecetes bairdi (Isolate designation \#3) and $C$. opilio (Isolate designation \#4). There was no nucleotide variation either within isolates of $H$. cf. perezi or within isolates of Hematodinium-like organisms from $C$. bairdi. No sequence was obtained from $H$. australis because the amplified product was very faint (see Hudson \& Adlard 1994) as a result of degraded DNA from the original sample.

Using the BLAST routine on the partial SSU region of the Hematodinium organisms, the nucleotide se- 
1) Hematodinium \#1

(2) Henatodinium \#2

(3) Hematodinium $\# 3$

(4) Hematodinium $\$ 4$

(5) P. micans

(6) G. viscum

(7) S. microadriaticum

(8) S. corculormm

(9) S. pilosum

(0) S. meandrinae
$1 \quad$ Primer $1 \quad 1 \quad 1 \quad$ Primer $3 \quad 179$ GTTCCCCTTGAACGAGGAATCCTAGTAAGCGCGAGTCATCAGCTCGTGCTGATTACGTCCCTGCCCTTTGTACACACC

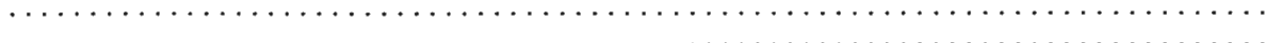

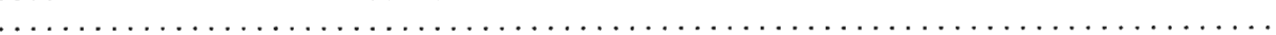

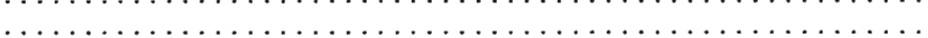

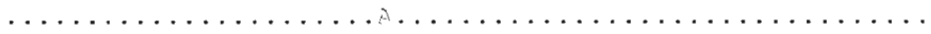

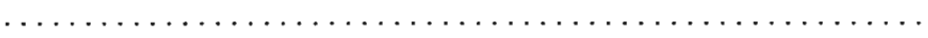

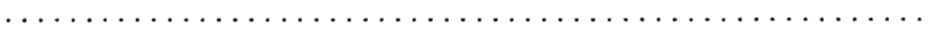

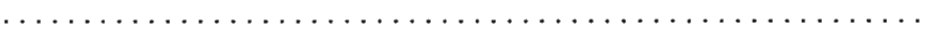

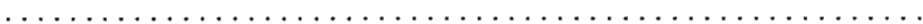

\section{I}

V9 Domain

(1.) GCCCGTCGCTCCTACCGATTGAGTGATCCGGTGAATAATICGGACGGCAGCCTTTTCCAGTTTCTGGAAGTGGCAGCTGGAAGTTTAGTGAACCTTAT

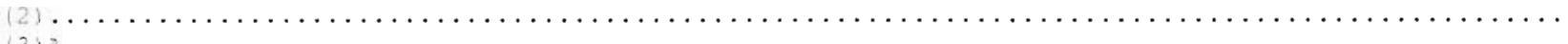

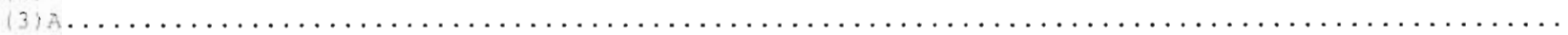

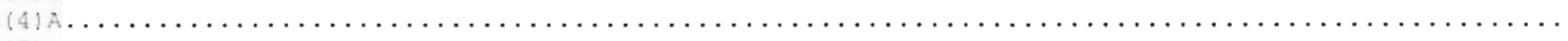

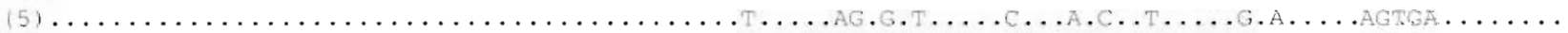

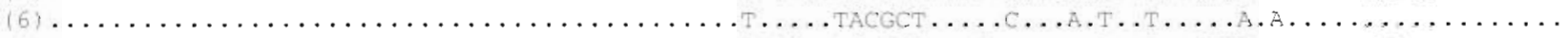

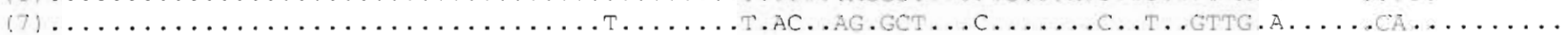

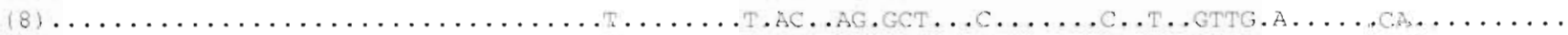

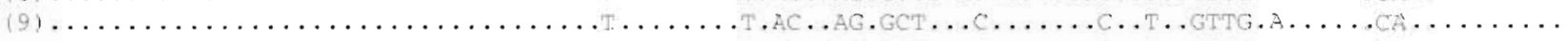

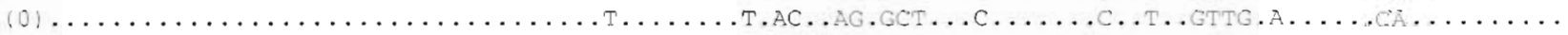

\section{[ $\quad$ Primer $4 \quad 1 \quad: 237$}

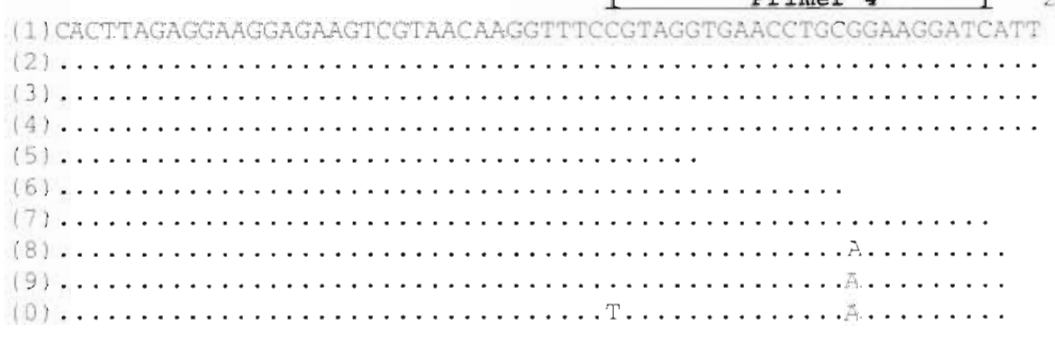

Fig. 1. Alignment of the nucleotide sequence from the 3' end of the small subunit (SSU) region of 4 types of Hematodinium (\#1 to \#4), Order Syndiniales: (1) H. cf. perezi from Callinectes sapidus, (2) Hematodinium-like dinoflagellate from Nephrops norvegicus. (3) Hematodinium-like dinoflagellate from Chionoecetes bairdi, (4) Hematodinium-like dinoflagellate from C. opilio; and 6 species from 3 other dinoflagellate orders: Order Prorocentrales, (5) Prorocentrum micans; Order Phytodiniales, (6) Gloeodinium viscum; Order Gymnodiniales, Family Zooxanthellaceae, (7) Symbiodinium microadriaticum, (8) S. corculorum, (9) S. pilosum, and (0) S. meandrinae. (·) Identical nucleotide
(1) Hematodinium *1
(2) Hematodinium \#2
(3) Hematodinium \#3
(4) Hematodinium \#4

/ ITS1

CGCACGAATAAGGTATCTTTGTATTATTAGTCGAACACAAGAGATGCACCGTGGAAGCTAGGCCATCAGCTACGACGACT ........ TCA. AAAAAACACCG. GAA . TTGG. C. TTAGG. AGGA. CAA. AAGC. CATGCGCATGTT.GATGAC ....... . A. AAAAAACACCG. GAA . TTGG.C.TTAGCA. -GA.CAA. AAGC. CATG. GCATGCT . CATG.C ....... . A. AAAAAACACCG.GAA. TTGG.C.TTAGCA. - GA. CAA . AAGC.CATG. GCATGCT.CATG.C

(1) ACTAGTTAGTTACTGAGTGGGGGGGCGGTGNNAGTTGGCGAATACTGCTATTTCTTACTCGCCGTTGAACTGCACAAAAAATAGTACCCCTCTCTTGTIG

(2) C.CG.CGCCGTCGACGCCTCC. - T. T.TGTGTGTG. . TGTGGGGG . TGTGCG. G. G. G. AT. CGCTCTAATA. GGG. TTCG. TC. ATGGGGAACACACC

(3) C. . GCCGCCG-..--CCTCC.CT.T.TGTGTGTG. .TGTGGGGG. .TGTGTGTG.G. . . T. CG . CTACTA.GGGGTGTG. . GATGGGGAAC-CACC

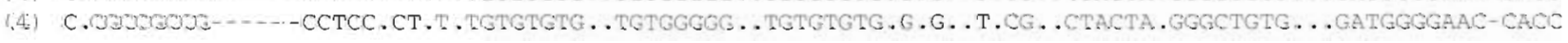

(1) GTAGGAGAaGTAGCTTCTACGGGGTGTGAGGTACGGCGGTAGTACACGACTACCACTGAACTTCTCCATCCCACGTUTGGTGCCCATAAATACAACA

(2) TCTCTCATTTATTT. . . . GATAAAAGCGT. T. CTCTTCAAT. ACT. TAC.CCT . T. A. CAC. AATTCACTTTATAACTG . . . TTCTTCCC. CCTA

(3) TCTCC.A.TA.TTC.C.AG. CCACGTGTGTTC. C. TTATAATAACTCTCTAAT.ACACTT. TACAATT . AACTAAGC. TC.T.T. CCCTTCC.TT . I

(4) TCTCC.A.TA.TTC.C.AG.CCACGTGTGTTT.C.TTATAATAACTCTCTAAT. ACACTT. TACAATT . AACTAAGC.TC.T.T.CCCCTCC.TT.T

Fig. 2. Alignment of the nucleotide sequence from the $3^{\prime}$ end of the small subunit (SSU) region and the $5^{\prime}$ end of the ITS1 region of 4 types of Hematodinium (\#1 to \#4): (1) H. cf. perezi from Callinectes sapidus, (2) Hematodinium-like dinoflagellate from Nephrops norvegicus, (3) Hematodinium-like dinoflagellate from Chionoecetes bairdi, (4) Hematodinium-like dinoflagellate from $C$. opilio. $(\cdot)$ Identical nucleotide; $(-)$ missing nucleotide; $(N)$ indeterminate nucleotide 
quence showed similarities to other dinoflagellates (Fig. 1). H. cf. perezi (\#1) showed a $92.2 \%$ (179 bases) similarity to Gloeodinium viscum over 194 bases; it also showed a $92.2 \%$ (200 bases) similarity to Prorocentrum micans over 217 bases and $90.2 \%$ (193 bases) similarity for the 3 species of Symbiodinium over 214 bases and $89.7 \%$ (192 bases) similarity for S. meandrinae over 214 bases. Fig. 1 also shows that of the 237 bases obtained from the $3^{\prime}$ end of the Hematodinium organisms (\#1 to \#4), the region between bases 110 and 170 (125 to 65 bases upstream from the SSU/ITS1 boundary) was highly variable when compared to the other dinoflagellates. In this region of 60 bases, $H$. cf. perezi showed a $78.3 \%$ (47 bases) similarity to G. viscum with 9 informative sites; $H$. cf. perezi showed a $73.3 \%$ ( 44 bases) similarity to $P$. micans with 8 informative sites; and showed a $68.3 \%$ (41 bases) similarity to the 4 Symbiodinium spp. with 5 informative sites (Table 1). In this variable region there were no differences between the 4 species of Symbiodinium and the 4 types of Hematodinium. Within the 4 types of Hematodinium there was 1 base difference (position 80) between the Hematodinium-like dinoflagellates from Chionoecetes bairdi and $C$. opilo and the other 2 Hematodinium organisms.

In the partial ITS1 region (Fig. 2), H. cf. perezi (\#1) showed a $22.7 \%$ (63 bases) similarity with Hematodinium \#2 with 19 informative sites and 1 deletion over 278 bases; $H$. cf. perezi showed a $25.9 \%$ (72 bases) similarity for both Hematodinium \#3 \& \#4 with 16 informative sites and 3 deletions over 278 bases; Hematodinium \#2 showed a $66.5 \%$ (185 bases) similarity for both Hematodinium \#3 and \#4 with 139 informative sites and 4 deletions over 278 bases; Hematodinium \#3 showed a $99.3 \%$ (276 bases) similarity over 278 bases with Hematodinium \#4 (Table 2).

\section{DISCUSSION}

Hematodinium australis can be distinguished from $H$. cf. perezi by its larger vegetative stage, its round as opposed to vermiform plasmodium, its austral geographic location, and by its different host species. The trophont of $H$. australis differs from the Hematodinium-like organisms from Chionoecetes bairdi and
Table 2. Similarity matrix for the partial ITS1 region for the 4 Hematodinium organisms

\begin{tabular}{|cccc|}
\hline & $\begin{array}{c}\text { Hemato- } \\
\text { dinium } \# 1\end{array}$ & $\begin{array}{c}\text { Hemato- } \\
\text { dinum } \# 2\end{array}$ & $\begin{array}{c}\text { Hemato- } \\
\text { dinium \#3 }\end{array}$ \\
\hline Hematodinium \#1 & - & & \\
Hematodinium \#2 & $22.7 \%$ & - & - \\
Hematodinium \#3 & $25.9 \%$ & $66.5 \%$ & - \\
Hematodinium \#4 & $25.9 \%$ & $66.5 \%$ & $99.3 \%$ \\
\hline
\end{tabular}

C. opilio in that it is smaller, possesses trichocysts, and has the small form of beaded chromatin. H. australis differs from the Hematodinium-like organism from Nephrops norvegicus in that the trophont stage is larger, it possesses the small form of beaded chromatin, and it does not appear to have the vermiform plasmodium (Hudson \& Shields 1994). The Hematodinium-like organisms from $N$. norvegicus, $C$. bairdi and $C$. opilio differ from $H$. cf. perezi in that they possess the large form of beaded chromatin, while the larger trophont size and absence of trichocysts in the Hematodinium-like organisms from $C$. bairdi and $C$. opilio differentiates them from that of $N$. norvegicus (see Table 3).

Changes in morphological/biological characters can be induced either by the immediate environment of the parasite, e.g. the host and its own environment, or by the direct expression of different genomes. To test whether the morphological differences that exist for Hematodinium organisms are phenotypic or genotypic responses we examined the partial nucleotide sequence of the $3^{\prime}$ end of the SSU gene from 2 isolates of $H$. cf. perezi and Hematodinium ex $C$. bairdi and 1 isolate of the other 2 Hematodinium organisms. One of the criteria for selecting a tandemly repeated unit such as the rDNA gene is that these units are subject to concerted evolution which tends to homogenize sequences among individuals and among populations (Dowling et al. 1990). Therefore, only a small number of isolates are required to type genetically each organism. Sogin \& Elwood (1986) stated that in the SSU gene there were 2 regions that drift very rapidly in all eucaryotic rDNA and one of these is situated in the $3^{\prime}$ end of the SSU gene. This region, the V9 domain (see Neefs et al. 1990 for nomenclature) is situated approx-

Table 1. Similarity matrix showing relatedness ( $\%$ homology) in the V9 domain of the partial small subunit (SSU) region for the 4 Hematodinium organisms (Hem $\# 1-4$ ) and the 6 dinoflagellates: Prorocentrum micans (P. mic.); Gloeodinium viscum (G. vis.): Symbiodinum microadriaticum (S. mic.); S. corculorum (S. cor.), S. pllosum (S. pil.); and S. meandrinae (S. mea.)

\begin{tabular}{|c|c|c|c|c|c|c|c|}
\hline & Hem \#1-4 & P. mic & G. VIS. & S. mic. & S. cor. & S. pil. & S. mea. \\
\hline $\begin{array}{l}\text { Hematodinium } \\
\text { organisms \#1-4 }\end{array}$ & $100 \%$ & $73.3 \%$ & $78.3 \%$ & $68.3 \%$ & $68.3 \%$ & $68.3 \%$ & $68.3 \%$ \\
\hline
\end{tabular}


Table 3. Characteristics of vegetative stages of different species and forms of Hematodınium from various hosts. V: veriform $R$ : round; N.O.. not observed

\begin{tabular}{|c|c|c|c|c|}
\hline $\begin{array}{l}\text { Species: } \\
\text { Host: }\end{array}$ & $\begin{array}{l}\text { H. perezi } \\
\text { C. sapidus }\end{array}$ & $\begin{array}{l}\text { H. australis } \\
\text { P. pelagicus }\end{array}$ & $\begin{array}{c}\text { H-like } \\
\text { N. norvegicus }\end{array}$ & $\begin{array}{l}\text { H-like } \\
\text { C. bairdi }\end{array}$ \\
\hline Average size $(\mu \mathrm{m})$ & $6.4-10.4$ & $9.9-11.9$ & $6-10$ & $12.8-15.6$ \\
\hline Plasmodium form & V & $\mathrm{R}$ & $V \& R$ & $\mathrm{R}$ \\
\hline Presence of trichocysts & Yes & Yes & Yes & No \\
\hline Chromatin pattern & Small & Small & Large & Large \\
\hline Dinospores present & N.O. & N.O. & Yes $^{\text {a }}$ & Yes \\
\hline \multirow[t]{2}{*}{ Water temp. } & Jan-Jul & Jul-Dec & Mar-Apr & Jun-Aug \\
\hline & $4-26^{\circ} \mathrm{C}$ & $17-26^{\circ} \mathrm{C}$ & $10-13 c:$ & $6.2^{\circ} \mathrm{C}$ \\
\hline
\end{tabular}

imately between 125 and 65 bases upstream of the SSU/ITS1 boundary. The V9 domain was present in the partial sequence of the 3 ' end of the SSU gene from the 4 Hematodinium organisms, and the analysis of its sequence provided a clear indication of the genetic status of the Hematodinium-like organisms.

Differences exist between other orders of dinoflagellates in the V9 domain. We found between 24 and $34 \%$ difference in nucleotide sequence in the V9 domain. when we compared 2 free-living orders of dinoflagellates ( 1 species in each) and 1 symbiotic order of dinoflagellate (1 family, 4 species) to a parasitic order containing $H$. cf. perezi. Differences have also been observed between families in the same order in the V9 domain. Nucleotide sequence differences of $70 \%$ occurred in the V9 domain of 2 hypotrich ciliates, Oxytricha granulifera (Oxytrichidae) (Schlegel et al 1991) and Euplotes aediculatus (Euplotidae) (Sogin \& Elwood 1986). Furthermore, comparison of the V9 domain of 2 genera, Onychodromus quadricornutus and Oxytricha granulifera, within the same family (Oxytrichidae) showed $18.3 \%$ difference in nucleotide sequence (Schlegel et al. 1991). Species level comparison within the V9 domain of the free-living ciliate genus Tetrahymena showed 13 species that fell into 2 major homology groups with $10 \%$ difference in nucleotide sequence over this region (Sogin et al. 1986). However, no differences occurred between 4 species of symbiotic dinoflagellate Symbiodinium spp. In 2 congeneric species of parasitic protozoa, the coccidian Cryptosporidium displayed a $99 \%$ similarity over the SSU gene, but none of these differences occurred within the V9 domain (Cai et al. 1992). From this data there were sequence differences in the V9 domain between representatives of the same order but 2 different families (holotrichous ciliates), and between representatives of the same family but 2 different genera (Onychodromus and Oxytricha). Between congeneric species, there were both differences (Tetrahymena) and no differences (Symbiodinium and Cryptosporidium).
High levels of homology within the V9 domain of these protistans appear indicative of 'generic' status when compared with classical morphological systematics. No differences occurred in the V9 domain of the 4 Hematodinium organisms, and only 1 site varied (99.6\% similarity) in the remaining partial SSU sequence. As only a partial SSU sequence was investigated, it is possible that nucleotide differences between Hematodinium and Hematodinium-like organisms could occur elsewhere in the SSU gene. Rowan \& Powers (1992) showed that in the partial SSU of 2 dinoflagellates, Symbiodinium microadriaticum and $S$. pilosum, there were only 2 nucleotide differences in 478 bases, even though they are very different from each other by morphological, biochemical, physiological and behavioral criteria. However, we believe that the evidence derived from the highly variable V9 domain strongly suggests that the Hematodinium-like organisms should be considered to be within the genus Hematodinium. It is worthy of note that without investigation of confamilial genera no definitive placement of cryptic species within a genus can be made.

Assuming the Hematodinium-like dinoflagellates from Chionoecetes bairdi, C. opilio and Nephrops norvegicus are in the same genus as $H$. cf. perezi, we then compared the partial ITS1 sequence to determine the extent of genetic variance between the 4 Hematodinium organisms. ITS regions evolve fast and may vary among species within a genus or among populations (Lee \& Taylor 1992). The large variation of the partial ITS1 region between $H$. cf. perezi and Hematodinium \#2, \#3 and \#4 is consistent with morphological characters. Hematodinium \#2, \#3 and \#4 have round plasmodia and large beaded chromatin, whereas $H$. cf. perezi has vermiform plasmodia and small beaded chromatin. Even with the morphological similarities between \#2, \#3 and \#4, \#2 varied substantially from \#3 and \#4, whereas there was only 2 base differences between $\# 3$ and \#4 in the partial ITS1 region and no differences in the partial SSU gene. 
Comparison of 2 congeneric species of coccidian parasites, Cryptosporidium parvum and C. muris, revealed only 1 major difference between the species over the complete ITS1 region of 381 bases (Cai et al. 1992). Goggin (1994) concluded that 2 species of apicomplexan protists, Perkinsus atlanticus and P. olseni, belonged to a single species as they were similar over the complete ITS1 region of 196 bases and the $5.8 S$ and the ITS 2 regions, while both showed a $23 \%$ sequence difference in the ITS1 region when compared to a third species. Differences in nucleotide sequence in the partial ITS1 regions from these 4 Hematodinium organisms suggest that there are 2 new species. The Hematodinium organism ex $N$. norvegicus warrants the creation of a new species. The Hematodinium organisms ex $C$. bairdi and $C$. opilio are probably the same species residing in different hosts and warrant the creation of another new species, while $H$. cf. perezi remains distinct from the other isolates. However, we stop short of erecting new species until sequence data becomes available for confamilial genera within the Order Syndiniales (sensu Taylor 1987), e.g. Syndinium and Trypanodinium which both have representatives parasitic in crustacea. Only then can a new diagnosis of the genus Hematodinium be made.

Acknowledgements. We thank Drs Rob Field. Ted Meyers and Sally Short; and Jeff Shields for providing us with samples of host and Hematodinium spp. from Scotland Alaska and Virginia, respectively. We also thank the 3 anonymous reviewers for their helpful criticism of this manuscript.

\section{LITERATURE CITED}

Adlard RD, Barker SC, Blair D, Cribb TH (1993) Comparison of the second internal transcibed spacer (ribosomal DNA) from populations and species of Fasciolidae (Digenea). Int J Parasitol 23:423-425

Altschul SF, Gish W, Miller W, Myers EW, Lipman DJ (1990) Basic local alignment search tool. J molec Biol 215:403-410

Cabot EL, Beckenbach AT (1989) Simultaneous editing of multiple nucleic acid and protein sequences with ESEE. Comput appl Biosci 5:233-234

Cai J, Collins MD, MCDonald V, Thompson DE (1992) PCR cloning and nucleotide sequence determination of the $18 \mathrm{~S}$ rDNA genes and internal transcribed spacer 1 of the protozoan parasites Cryptosporidium parvum and Cryptosporidium muris. Biochim Biophys Acta 1131:317-320

Chatton E, Poisson R (1931) Sur l'existence, dans le sang des crabs, de peridiniens parasites Hematodinium perezi n. $g$. n. sp. (Syndinidae). Cr Séanc Soc Biol 105:553-557

Diggles BK, Adlard RD (1995) Taxonomic affinites of Cryptocaryon irritans and Ichthyophthirius multifilis inferred from ribosomal RNA sequence data. Dis aquat Org 22(1): $39-43$

Dowling TE, Moritz C, Palmer JD (1990) Nucleic acids II: restriction site analysis. In: Hillis DM, Moritz C (eds) Molecularsystematics. Sinauer, Sunderland, Massachusetts, p 250-317
Field RH, Chapman CJ, Taylor AC, Neil DM., Vickerman K (1992) Infection of the Norway lobster Nephrops norvegicus by a Hematodinium-like species of dinoflagellate on the west coast of Scotland. Dis aquat Org 13.1-15

Goggin CL (1994) Variation in the two internal transcribed spacers and 5.8S ribosomal RNA from five isolates of the manne parasite Perkinsus (Protista, Apicomplexa). Mol Biochem Parasitol 65:179-182

Hudson DA, Adlard RD (1994) PCR techniques applied to Hematodinium spp. and Hematodinium-like dinoflagellates in decapod crustaceans. Dis aquat Org 20:203-206

Hudson DA, Shields JD (1994) Hematodinium australis n. sp., a parasitic dinoflagellate of the sand crab Portunus pelagicus from Moreton Bay, Australia. Dis aquat Org 19: 109-199

Lee SB, Taylor JW (1992) Phylogeny of five fungus-like protoctistan Phytophthora species, inferred from the internal transcribed spacers of ribosomal DNA. Mol Biol Evol 9: $636-653$

Messick GA (1994) Hematodinium perezi infections in adult and juvenile blue crabs Callinectes sapidus from coastal bays of Maryland and Virginia, USA. Dis aquat Org 19: $77-82$

Meyers TR, Koeneman TM, Botelho C, Short S (1987) Bitter crab disease: a fatal dinoflagellate infection and marketing problem for Alaskan Tanner crabs Chionoecetes bairdi. Dis aquat Org 3:195-216

Neefs JM, Van de Peer Y, Hendriks L, De Wachter R (1990) Compilation of small ribosomal subunit RNA sequences. Nucleic Acids Res 18:2237-2317

Newman MW, Johnson CA (1975) A disease of the blue crabs (Callinecies sapidus) caused by a parasitic dinoflagellate, Hematodinium sp. J Parasitol 63(3):554-557

Porter $\mathrm{CH}$, Collins FH (1991) Species-diagnostic differences in a ribosomal DNA internal transcribed spacer from the sibling species Anopheles freeborni and Anopheles hermsi (Diptera: Culicidae). Am J trop Med Hyg 45: 271-279

Rowan R, Powers DA (1992) Ribosomal RNA sequences and the diversity of symbiotic dinoflagellates (zooxanthellae). Proc natl Acad Sci USA 89:3639-3643

Sanger F, Nicklen S, Coulsen AR (1977) DNA sequencing with chain terminating inhibitors. Proc natl Acad Sci USA $74: 5463-5467$

Schlegel M, Elwood HJ, Sogin ML (1991) Molecular evolution in hypotrichous ciliates: sequence of the small subunit ribosomal RNA genes from Onychodromus quadricornutus and Oxytricha granulifera (Oxytrichidae, Hypotrichida, Ciliophora). J molec Evol 32:64-69

Shields JD (1994) The parasitic dinoflagellates of marine crustaceans. A Rev Fish 4:241-271

Shields JD, Wood FEI (1993) Impact of parasites on the reproduction and fecundity of the blue sand crab. Portunus pelagicus from Moreton Bay, Australia. Mar Ecol Prog Ser 92:159-170

Sogin ML, Elwood HE (1986) Primary structure of the Paramecium tetraurelia small subunit rRNA coding region: phylogenetic relationships within the Ciliophora. J molec Evol 23:53-60

Sogin ML, Ingold A, Karlok M, Nielson H, Enberg J (1986) Phylogenetic evidence for the aquisition of ribosomal RNA introns subsequent to the divergence of some of the major Tetrahymena groups. EMBO J 5:3625-3630

Taylor FJR (1987) Appendix: taxonomy and classification. In: Taylor FJR (ed) The biology of the dinoflagellates. Blackwell Scientific Publications, Oxford, p 723-731 